Veljko Marinković ${ }^{\star}$, Darko Dimitrovski², Vladimir Senić ${ }^{2}$

${ }^{1}$ University of Kragujevac, Faculty of Economics, Kragujevac, Serbia

${ }^{2}$ University of Kragujevac, Faculty of Hotel Management and Tourism, Vrnjačka Banja, Serbia

\title{
Towards Developing a Sustainable Tourism Destination: Understanding Motives of Gold Panning on the River Pek
}

DOI: 10.7595/management.fon.2018.0013

\begin{abstract}
Research question: The aim of the paper is to identify the statistically significant drivers for gold panning revisit intention at the River Pek in Serbia as one of the key factors in determining a positive effect on the destination's economic sustainability. Motivation: The paper measures the effects of learning, socialization, nature and prestige and their influence on revisit intention. Idea: The core idea of this paper was to empirically evaluate the relationship between recogized tourism motivation as an independent variable and revisit intention as a dependent variable, given that revisit intention represents an important indicator regarding the sustainablity of an emerging tourist destination. Data: Empirical research was conducted on a sample of 230 respondents. A convenience sample was used and was constructed of people who had visited the River Pek as members of organized groups. Tools: Analysis of the data was conducted in SPSS and Amos. The statistical analysis was implemented in two steps. Since this model contains one dependent and four independent variables, its validity has been tested by means of a confirmatory factor analysis. In order to test the significance and strength of the effects independent of the dependent variable, a structural equation model was applied. Findings: The findings of the research suggest that two variables are statistically significant triggers of revisit intention - nature and prestige. Obviously, tourists are likely to engage in the activity of gold panning due to having a desire to experience something new and exciting, which is considerably different from their everyday activities, as well as from other types of tourism. Contribution: The main contribution of the study is to describe in more detail the concept of gold panning and its potential - as a form of niche tourism - to contribute towards establishing the River Pek as a sustainable tourist destination. The study also contributes to existing literature through the implementation of quantitative research of the motives for gold panning.
\end{abstract}

Keywords: gold panning, learning, socialization, nature, prestige, revisit visit, Serbia

JEL classification: M31, Z30.

\section{Introduction}

The demand in the global market for interesting and unique tourist activities that foster establishing sustainable tourist destinations - in terms of environment, society and economy - continues to rise annually. Thus, a new type of tourism known as 'special interest' tourism (or 'niche' tourism) has emerged in recent years. The special interest tourism comprises different activities in the tourism context such as visits to wine-producing regions, adventure tourism and volunteering. It is among these activities that gold panning can be included.

Throughout history, humans have been fascinated with gold. This fascination is not easy to explain and it has inspired both creativity, and art-making, just as much as it has greed and the most ferocious of crimes. The precious metal was always - for the most part - mined, but with the introduction of gold panning, the quest for gold became a global phenomenon. The initial gold rushes were geographically linked to California, but in modern times, this fever-like state is found all over the world, including Serbia. Unlike in days gone by, gold panning today does not have extensive commercial characteristics, it rather emerges as a popular leisure activity, mainly being engaged in by those who live in urbanized areas. Gold panning in this sense is usually undertaken in more remote and economically passive, rural areas. As a result, it has inevitably grown into a component of tourist itineraries, either as an individual, stand-alone excursion or as part 
of a larger organized tour. Over a prolonged period of time, the promotion of gold panning as a tourist activity could provide a significant stimulus to a local economy, as well as contribute to the preservation of local non-material heritage. In addition, gold panning can be considered as being a physical activity that could have a positive influence on improving mental and physical health. It certainly contains elements of adventurism, which is particularly evident when deciding upon the correct location to undertake the activity, as well as the adrenaline rush at the moment when gold in first glimpsed at the bottom of the pan.

There is a lot of potential for Serbia to develop a number of unique and sustainable tourist destinations, while allowing national tourist authorities to position Serbia even better on an already competitive global tourist market map. As a result, there is a need to determine the basic factors that motivate tourists into deciding to initially participate in the activity, and then opt to revisit the sites where they can engage in gold panning. Thus, the objective of the paper is to determine the statistically relevant triggers that lead a tourist to decide to make a repeated visit to the River Pek for gold panning. The main contribution of this research is its study of one particular type of special interest tourism activity, as well as the use of quantitative research with the goal of defining the motives behind gold panning.

\section{Literature Overview}

\subsection{Motivation in tourism}

Given that the motivation for participation in gold panning, as a type of special interest tourism, is not yet adequately researched (Marinkovic et al., 2017), it is necessary to gain a better insight into the wider context of motivation that is specific to tourism and leisure. People usually decide to travel for various reasons and motives, explaining them as forces that reduce the state of tension (Correia et al., 2007). The tourist motivation is a "multi-faceted" (McCabe, 2000) phenomenon, given that tourists have different motivations, even when concerning a single journey. The heterogeneous nature of tourist motivation is recognized by many researchers (Cohen, 1972; Plog, 1974; Dann, 1977), which has resulted in the development of different typologies of tourists based on the relationship between personality and tourist activity. Pizam et al. (1979) mention that motivation in tourism is related to a set of needs that cause a person to engage in a certain tourist activity. The identification of the motives that lead to participation in a given tourist activity can be viewed as a vital variable, which, when understood, can generate a satisfactory tourist experience (Crompton, 1979; Fodness, 1994). Therefore, only a complete understanding of the key motives for participating in a given tourist activity can ensure an adequate management of it and thus lead to the feeling of confidence that visitors are more likely to have the experience they desire and their needs satisfied (Beh \& Bruyere, 2007).

In academic literature, a number of theoretical frameworks are used for explaining tourist motivation. These include Dann's (1979) 'Push' and 'Pull' Factors, which interprets tourist motivation through the notion of unevenness (Crompton, 1979); Complexity Theory (Mayo \& Jarvis, 1981); the Dichotomous Model (personal and interpersonal dimension) Iso-Ahole (1983); and the Travel Career Ladder (TCL) - an approach introduced by Pearce et al. (1988). Dann (1977) introduces perhaps the most frequently used approach to investigating motivation in tourism (Cohen, et al., 2014; Prayag \& Hosany, 2014). The method involves researching into two different but related aspects - 'push' and 'pull' factors. Push factors represent a tourist's intrinsic motivation, while pull factors are related to characteristics of the destination itself. Push factors have an impact on creating a need for traveling, while pull motives are responsible for selecting the destination to which to travel (Uysal \& Jurowski, 1994).

Hall and Page (2014) refer to tourism and leisure as activities among which there is no clear distinction, so the motives for these activities are viewed as similar. Therefore, in the research on the motivation underlying activities related to tourism and leisure, it is possible to employ a similar methodology (Moore et al., 1995). People practice certain activities in their spare time in order to satisfy certain needs which are also at the core of tourist activities (Driver \& Tocher, 1970). The similarities between tourism and leisure are bound to rooted habits related to leisure activities that tourists engage in during their travel, thus representing the 'leisure tourism continuum' (Carr, 2002). The four types of motivation (nature, prestige, social interaction and learning) that are recognized as significant for the purposes of the study will be clarified in more detail as separate concepts.

\subsection{Key motives for gold panning as a tourist activity}

The overview of tourist literature has identified some factors that have an impact on the decision whether to participate in a given tourist activity, among which 'learning', 'socialization' and 'prestige' are specifically stressed (Kim \& Prideaux, 2005). The motives previously identified are mentioned by other authors (Cromp- 
ton, 1979; Fodness, 1994; Pearce \& Lee, 2005). The need for spending time in the countryside and nature leans on these same motives, and is just as important from the perspective of tourism and leisure. Interestingly, Kozak (2002), based on the results of his study, concluded that certain nationalities are more inclined to favor tourist activities in natural settings. In the light of this, a number of motivations have been recognized as significant to the study and will be further discussed.

\section{Nature}

Pearce et al. (1998) suggest the ten most important travel motives, of which four are related to nature. Beh and Bruyere (2007) refer to nature as one of the motives when it comes to visiting national parks. Driver (1976) stresses the significance of recreation in nature as an important type of human need. Also, Thompson (2002) mentions an approach to nature as important human need, especially if the positive effects that result from direct contact with nature are taken into consideration. Nature is an important characteristic of an activity such as gold panning, especially because it is exclusively available in areas with outstanding natural beauty. To a great extent, direct contact with nature, which in this case is realized by being centered along the river and being at the waterside, determines the satisfaction level with the activity itself. Activities in the natural environment provide psycho-physical benefits (Kim \& Eves, 2012), have a positive effect on stress (Ulrich et al., 1991), and generally have a positive effect on health. Given that these areas are usually inaccessible, the negative effect of human factors is diminished, thus instilling nature as a significant motive in deciding to participate in gold panning activity.

\section{Prestige}

Riley (1995) defines prestige within the framework of tourist consumption as a motivation used by individuals as a means of getting respect from the wider community, by consuming tourist experiences that are seen as prestigious. Crompton (1979) and Dann (1977) were among the first authors to identify prestige as an important factor of motivation in tourism. In general, people have a need to distinguish themselves from others, and one of the ways to do so is related to how they use their spare time and what tourist/leisure activities they indulge in. O'Reilly (2006) has concluded that certain types of tourism are not that accessible to a wide range of potential tourists, and therefore constitute tourist activities that point to prestige. A tourist's desire to be acknowledged by society, as well as a motive to strengthen their social status, self-esteem and ego (Dann, 1977; Iso-Ahola, 1983) are important reasons as to why tourists decide to participate in unusual tourist activities. Gold panning is certainly an activity that is not mainstream or widely available and as such, it can be viewed as a status symbol or simply a matter of prestige. Participating in this activity can be used by an individual to distinguish themselves in their own social environment and attract certain attention and recognition.

\section{Social interaction}

Socialization in spare time and tourism is an important aspect of previously mentioned activities (Ryan \& Deci, 2000). Park et al. (2009) refer to socialization as an essential factor when it comes to activities in nature. Gathering of people with shared interests is the core of tourism, as it gives rise to the possibility of meeting others, sharing experiences and making new friends (Ryan and Glendon, 1998). Gold panning is a dynamic activity that involves a large group of people who actively participate in the process itself, but also communicate with one another and share experiences. This provides them with a sense of being part of a team. Given that gold panning is likely to attract individuals with similar interests, socialization surfaces as an important factor in the decision-making process as to whether to participate in the activity.

\section{Learning}

Educational components have always gone beyond the framework of formal education (Broomhall et al., 2010), hence the possibility of learning in the informal context of activity is a very important aspect of the tourism experience. A possibility to learn and find out something new has always driven the desire for travel. Pearce and Lee (2005) maintain that learning might not only be a key motivational factor for tourism at a young age, but also for those who are older. Activities which share similar characteristics to gold planning are found in other leisure time pursuits (Stebbins, 1982), which can be classed as 'serious leisure' - that is, activities which involve gaining experience and obtaining skills and knowledge. So gold panning naturally fits into this category. According to Pine and Gilmore (1999), learning is viewed as a critical element of tourist experiences which demand active participation - another important characteristic of gold panning. The activity of gold panning itself can also be viewed in the context of heritage tourism within which learning represents the essence of travel itself (Moscardo, 1996; Poria, et al., 2004). In that context, gold panning locations can be used as educational sites where a local instructor actively involves tourists in a certain activity, but also promotes the cultural heritage of the local community. Given that the location and the history 
of the activity itself are closely intertwined with myth and legend, the significance of learning again comes to the fore (Rid et al., 2014). With this being the case, the well-known legend of the Argonauts and the Golden Fleece can therefore be linked with the River Pek and used as one of many examples of potential use of education related to gold panning as a tourist experience.

\section{The Methodology and Results of the Empirical Research}

Empirical research of the factors which have an impact on tourists' willingness to visit the River Pek for the purpose of gold panning activity was conducted on a sample of 230 respondents. A convenience sample was used and was constructed of people who had visited the River Pek as part of organized groups. The River Pek is a suitable location within Serbia for monitoring tourist activity related to gold panning and interviewers approached respondents who had completed a visit to the River Pek. The respondents were Serbian tourists who were nature enthusiasts who had visited the River Pek with the aim of engaging in gold panning activity, as well as to rest and enjoy the environment surrounding the river. Given that the River Pek is mainly visited by smaller groups of tourists, the data gathering was conducted on a number of occasions during the spring and summer of 2015.

The sample is mainly comprised of males, given that males show a stronger interest in gold panning activity than females. Male respondents accounted for $61.7 \%$ of the sample, with females accounting for $38.3 \%$. The majority of the sample belonged to the 18-to-24-year age group (40.9\%). The three other age groups account for similar proportions of the remainder of the sample, accounting for $18 \%$ to $21 \%$ of the sample. Regarding the education level of respondents, the majority of the sample had previously obtained a high school diploma (50.9\%), followed by a bachelor degree (30.4\%) and associate degree (18.7\%). Regarding marital status, the majority of respondents were single $(61.7 \%)$ and $38.3 \%$ of the sample were married.

The data were gathered by conducting a personal interview with the respondents. Interviewees expressed their attitudes on a seven-point Likert scale. All statements were grouped within five variables (learning, socialization, nature, prestige and revisit intention) where each variable was measured by a set of statements that reflect its essence. Such an approach is commonly employed in field marketing surveys. The research model involved four independent variables (learning, socialization, nature, prestige), whereby the significance and strength of their impact on the dependent variable (revisit intention) were tested. The overview of the model variables, as well as sources from which the statements were taken and adapted from for the purpose of the research is given in Table 1.

Table 1. Model variables

\begin{tabular}{|c|c|c|}
\hline Model variables & Source of used statements & Cronbach's alpha \\
\hline Learning & Park \& Yoon (2009) & 0.85 \\
\hline Socialization & Ryan \& Glendon (1998) & 0.85 \\
\hline Nature & Beh \& Bruyere (2007) & 0.85 \\
\hline Prestige & Correia \& Kozak (2012) & 0.91 \\
\hline Revisit intention & Dimitrovski \& Crespi-Vallbona (2017) & 0.81 \\
\hline
\end{tabular}

The analysis of the data was conducted in SPSS and Amos. The statistical analysis was implemented in two phases. First, the reliability and validity of the model were tested. The internal consistency of the statements used for measuring the model's latent variables was checked based on Cronbach's alpha values. Then, by employing confirmative factor analysis, the overall fit of the model was tested. In that respect, the indices' values as to the suitability of the research model were calculated (Chi-square / df; RFI - relative fix index; NFI - normed fit index; CFI - comparative goodness of fit; TLI - Tucker-Lewis Index; IFI - incremental fit index; RMSEA - root mean square error of approximation). Secondly, the individual impacts were calculated through the use of the structural equation model (SEM).

The internal consistency of the model variables was analyzed based on Cronbach's alpha values. In case of all the variables, the Cronbach's alpha values are above the minimum threshold of 0.7 (Nunnally, 1978). The highest level of internal consistency is found for the 'prestige' variable, where Cronbach's alpha value is 0.91 . The results of the analysis of internal consistency are shown in Table 1. Additional testing of the fit of the suggested research model was completed by employing the confirmative factor analysis. This analysis assumes calculation of a series of indices whose values determine the adequacy of the designated model. Based on all the indices calculated, adequate values were obtained for the model (Table 2). Value $X^{2} / \mathrm{df}$ is 1.36 and this value is below the threshold of 3.0 as suggested by Carmines and Mclver (1981). The values of the RFI, NFI, CFI, TLI and IFI indices are all above the threshold of 0.9 (Byrne, 1998). Finally, the 
RMSEA is lower than 0.1 (Steiger, 1990). Additional tests of model validity were performed by the analysis of confirmative factor loadings. Namely, these values for each individual statement are higher than 0.6 and statistically significant at the level of 0.05 .

Table 2. Indices of model fit

\begin{tabular}{|c|c|c|}
\hline Fit indices & Recommended value & Value in the model \\
\hline $\mathrm{X}^{2} / \mathrm{df}$ & $<3$ & 1.36 \\
\hline $\mathrm{RFI}$ & $>0.9$ & 0.918 \\
\hline $\mathrm{NFI}$ & $>0.9$ & 0.948 \\
\hline $\mathrm{CFI}$ & $>0.9$ & 0.985 \\
\hline $\mathrm{TLI}$ & $>0.9$ & 0.977 \\
\hline $\mathrm{IFI}$ & $>0.9$ & 0.985 \\
\hline $\mathrm{RMSEA}$ & $<0.1$ & 0.040 \\
\hline
\end{tabular}

The results of the SEM analysis are presented in Table 3. In accordance with the concept of the suggested model, a total of four relationships were tested. The research model is concerned with four potential factors that will trigger revisit intention in case of the River Pek. Two of the four effects emerged as statistically significant. These two effects are 'nature' and 'prestige', which were revealed to be significant triggers of revisit intention for the River Pek. The strongest impact on tourist revisit intention, related to the River Pek for the purpose of gold panning, comes from enjoying the natural environment and landscape $(\beta=0.225, p<$ 0.05). Evidently, tourists visit the River Pek not only for gold panning, but also in order to relax in the countryside and escape from everyday life.

Table 3. Results of SEM analysis

\begin{tabular}{|c|c|c|}
\hline Relations & $\boldsymbol{\beta}$ coefficient & Significance \\
\hline Learning $\rightarrow$ Revisit intention & 0.138 & n.s. \\
\hline Socialization $\rightarrow$ Revisit intention & 0.091 & n.s. \\
\hline Nature $\rightarrow$ Revisit intention & 0.225 & ${ }^{\star}$ \\
\hline Prestige $\rightarrow$ Revisit intention & 0.187 & ${ }^{\star *}$ \\
\hline
\end{tabular}

$* \star \beta$ value is significant at level of $0.01 ; * \beta$ value is significant at level of 0.05 ; n.s. $-\beta$ value is not statistically significant

The impact of prestige on the revisit intention is significant $(\beta=0.187, p<0.01)$. Gold panning is evidently also a matter of prestige - a more unusual and specific activity that offers a tourist an opportunity to experience something that their friends have not had the chance to experience. Therefore, the respondents believe that this type of tourism represents an opportunity to create a better personal image for themselves in the eyes of friends and acquaintances. On the other hand, the research did not confirm that learning and socialization had a significant impact on the revisit intention. This implies that tourists are not motivated to visit the River Pek and engage in gold panning in order to learn more about the history of the area or for the purpose of socialization. In this case, these motives are of no considerable significance.

\section{Conclusion and implications}

\section{Theoretical implications}

The study addresses the phenomenon of gold panning in the context of special interest tourism, which had not been adequately explored in the existing literature. The study contributes to the literature in the sense that it involved conducting quantitative empirical research and the use of the SEM analysis in order to understand the motives behind choosing gold panning as a tourist activity.

The findings of the research suggest that two variables are statistically significant triggers of revisit intention - which often represents one of the major components of a destination's long-term sustainability - are nature and prestige. Obviously, tourists are likely to engage in the activity of gold panning due to having a desire to experience something new and exciting, which is considerably different from their everyday activities, as well as from other types of tourism. For the respondents interviewed, gold panning is viewed as a matter of prestige. Prestige has previously been noted as an important motive for tourism (O'Reilly, 2006), for female tourists in particular in destinations that are characterized with untouched and unspoiled natural environments (Meng \& Uysal, 2008). Namely, they perceive that this specific type of tourism offers possibilities to experience something that most of their friends and acquaintances have never had the opportunity to experience themselves. Respondents are also willing to engage in this type of tourist activity due to the natural environment. 
Therefore, it can be inferred that respondents prefer to spend their time in nature and enjoy its beauty. The results obtained are in accordance with the conclusions made by Luo and Deng (2008), who stress that tourists are primarily motivated by experiencing closeness to nature and learning more about nature while they are still physically active. These findings have also been confirmed in many other studies (Weaver 2002; Tao et al., 2004).

\section{Managerial implications}

The research findings have managerial implications to travel agencies that plan to offer gold panning to tourists. These could include day trips or overnight excursions to the River Pek for this purpose. In their promotional campaigns, these travel agencies could stress the feeling of excitement, the possibility of prestige and the pristine natural surroundings that can be experienced as a result of taking part in gold panning. Emphasizing adventurism and the opportunity to try something new and exciting that is quite different from conventional excursions may likely prove to be something that interests some groups of would-be tourists and act as a motive to participate in the activity. Certainly, consideration should be given as to whether it is better to include gold panning as a short excursion, which is further complemented by time spent on the river, or as part of a longer itinerary such as a three- or five-day tour.

Without doubt, this type of tourism is worthy of further consideration, attention and promotion by the National Tourist Organization of Serbia, while respecting all necessary criteria related to developing a sustainable tourist destination. It is recommended that the natural beauty of the area and the excitement that can be found in visiting the River Pek are highlighted in promotional literature such as brochures and flyers. Definitely, gold panning is a type of tourist activity that can be considered unique, and one that could attract the attention of international tourists. When visiting a new country, many international tourists wish to experience something new that differentiates that country from others. In this sense, a tourist is looking forward to participating in something unusual or unique. As a result, it is important that this type of tourism is actively promoted and the natural environment and adventurism elements emphasized to potential tourists.

\section{Research limitations and suggestions for further research}

There are a number of limitations with regard to the research that was conducted. For one, it was only undertaken in one country. In that respect, the results cannot be generalized and widely applied to other populations and countries. In future studies, it may prove useful to undertake a cross-cultural analysis in order to compare the results of different nations. Additionally, it would be desirable to investigate the attitudes of both domestic and foreign tourists. A further analysis can also include demographic variables in order to determine the most important discerning factors between different genders, ages and education levels.

\section{Acknowledgments}

The earlier version of the paper was selected as the best paper at the conference "Challenges and Problems of Contemporary Marketing" (Izazovi i problemi savremenog marketinga), Zlatibor, Serbia, 17-19 November 2017. This research has been supported by the Serbian Ministry of Science and Technological Development - Grant number 41010.

\section{REFERENCES}

[1] Bagozzi, R.P., \& Yi, Y. (1988). On the evaluation of structural equation models. Journal of the Academy of Marketing Science, 16(1), 74-94. DOI:10.1007/BF02723327

[2] Beh, A., \& Bruyere, B. L. (2007). Segmentation by visitor motivation in three Kenyan national reserves. Tourism Management, 28(6), 1464-1471. DOI:10.1016/ j.tourman.2007.01.010

[3] Broomhall, S., Pitman, T., Majocha, E., \& McEwan, J. (2010). Articulating lifelong learning in tourism: dialogue between humanities scholars and travel providers. Canberra: Australian Learning and Teaching Council.

[4] Byrne, B. M. (1998). Structural equation modelling with LISREL, PRELIS, and SIMPLIS: Basic concepts, applications, and programming. Mahwah, NJ: Lawrence Erlbaum.

[5] Carr, N. (2002). The tourism-leisure behavioural continuum. Annals of Tourism Research, 29, 972-986. DOI:10.1016/S0160-7383(02)00002-6

[6] Carmines, E., \& Mclver, J. (1981). Analyzing models with unobserved variables: Analysis of covariance structures. In G. Bohmstedt \& E. Borgatta (Eds.), Social measurement: Current issues (pp. 61-71). Beverly Hills, CA: Sage.

[7] Cohen, E. (1974). Who is a tourist? A conceptual clarification. Sociological Review, 6, $408-424$. DOI:10.1111/j.1467-954X.1974.tb00507

[8] Cohen, S. A., Prayag, G., \& Moital, M. (2014). Consumer behaviour in tourism: Concepts, influences and opportunities. Current Issues in Tourism, 17(10), 872-909. DOI: 10.1080/13683500.2013.850064 
[9] Correia, A., \& Kozak, M. (2012). Exploring prestige and status on domestic destinations: The case of Algarve. Annals of Tourism Research, 39(4), 1951-1967. DOI:10.1016/j.annals.2012.06.005

[10] Correia, A., do Valle, P. O., \& Moco, C. (2007). Modeling motivations and perceptions of Portuguese tourists. Journal of Business Research, 60(1), 76-80. DOI:10.1016/j.jbusres.2005.10.013

[11] Crompton, J.L. (1979). Motivations of Pleasure Vacation. Annals of Tourism Research, 6(4), 408-424. DOI: 10.1016/0160-7383(79)90004-5

[12] Dimitrovski, D., \& Crespi-Vallbona, M. (2017). Role of food neophilia in food market tourists' motivational construct: The case of La Boqueria in Barcelona, Spain. Journal of Travel \& Tourism Marketing, 34(4), 475-487. DOI: 10.1080/10548408.2016.1193100

[13] Driver, B. L. (1976, September). Toward a better understanding of the social benefits of outdoor recreation participation. Paper presented at Southern States Recreation Research Applications Workshop.

[14] Driver, B. L., \& Tocher, S. R. (1970). Toward a behavioral interpretation of recreational engagements, with implications for planning. In B. L. Driver (Ed.), Elements of outdoor recreation planning (pp. 9-31). Ann Arbor: University of Michigan Press.

[15] Dann, M. S. (1977). Anomie, ego-enhancement and tourism. Annals of Tourism Research, 4, 184-194. DOI:10.1016/0160-7383(77)90037-8.

[16] Fodness, D. (1994). Measuring tourist motivation. Annals of Tourism Research, 21(3), 555-581. DOI:10.1016/0160-7383(94)90120-1

[17] Fornell, C., \& Larcker, D. F. (1981), Evaluating structural equation models with unobservable variables and measurement error. Journal of Marketing Research, 18, 39-80. DOI:10.2307/3151312

[18] Hall, M. C., \& Page, S. J. (2014). The geography of tourism and recreation: Environment, place and space. Abingdon, UK:Routledge.

[19] Iso-Ahola, S. E. (1983). Towards a social psychology of recreational travel. Leisure Studies, 2, 45-56. DOI:10.1080/02614368300390041

[20] Kim, Y. G., \& Eves, A. (2012). Construction and validation of a scale to measure tourist motivation to consume local food. Tourism Management, 33, 1458-1467. DOI:10.1016/j.tourman.2012.01.015

[21] Kim, S. S., \& Prideaux, B. (2005). Marketing implications arising from a comparative study of international pleasure tourist motivations and other travel-related characteristics of visitors to Korea. Tourism Management, 26(3), 347-357. DOI:10.1016/j.tourman.2003.09.022

[22] Kozak, M. (2002). Comparative analysis of tourist motivations by nationality and destinations. Tourism Management, 23(3), 221-232. DOI:10.1016/S0261-5177(01)00090-5

[23] Luo, Y., \& Deng, J. (2008). The New Environmental Paradigm and nature-based tourism motivation. Journal of Travel Research, 46(4), 392-402. DOI:10.1177/0047287507308331

[24] Marinkovic, V., Dimitrovski, D., \& Senic, V. (2017). Going for gold as a leisure tourism continuum: clustering motivations for gold panning revisit intention. Leisure Studies, 36(6), 764-777. DOI:10.1080/02614367.2016.1250803

[25] Mayo, E. J., \& Jarvis, L. P. (1981). The psychology of leisure travel. Effective marketing and selling of travel services. Boston, MA:CBI Publishing Company, Inc..

[26] McCabe, A. S. (2000). Tourism motivation process. Annals of Tourism Research, 27(4), 1049-1052. DOI:10.1016/S0160-7383(99)00130-9

[27] Meng, F., \& Uysal, M. (2008). Effects of gender differences on perceptions of destination attributes, motivations, and travel values: An examination of a nature-based resort destination. Journal of Sustainable Tourism, 16(4), 445-466. DOI:10.1080/09669580802154231

[28] Moore, K., Cushman, G., \& Simmons, D. (1995). Behavioral conceptualization of tourism and leisure. Annals of Tourism Research, 22, 67-85. DOI:10.1016/0160-7383(94)00029-R

[29] Moscardo, G. (1996). Mindful visitors: Heritage and tourism. Annals of Tourism Research, 23(2), 376397. DOI:10.1016/0160-7383(95)00068-2

[30] Nunnally, J.C. (1978). Introduction to Psychological Measurement. New York: McGraw-Hill.

[31] O'Reilly, C.C. (2006). From drifter to gap year: Mainstreaming backpacker travel. Annals of Tourism Research, 33(4), 998-1017. DOI:10.1016/j.annals.2006.04.002

[32] Park, D. B., \& Yoon, Y. S. (2009). Segmentation by motivation in rural tourism: A Korean case study. Tourism Management, 30(1), 99-108. DOI:10.1016/j.tourman.2008.03.011

[33] Pearce, P. L., \& Lee, U. I. (2005). Developing the travel career approach to tourist motivation. Journal of Travel Research, 43(3), 226-237. DOI:10.1177/0047287504272020

[34] Pearce, P. A., M. Morrison, \& J. L. Rutledge. (1998). Tourism: Bridges across Continents. Sydney, Australia: McGraw-Hill.

[35] Pine, B., \& Gilmore, J. H. (1998). Welcome to the experience economy. Harvard Business Review, 76(4), 97-105.

[36] Pizam, A., Neumann, Y., \& Reichel, A. (1979). Tourist satisfaction: Uses and misuses. Annals of Tourism Research, 6(2), 195-197. DOI:10.1016/0160-7383(79)90146-4

[37] Poria, Y., Butler, R., \& Airey, D. (2004). The meanings of heritage sites for tourists: The case of Massada. Tourism Analysis, 9(1), 15-22. DOI:10.3727/1083542041437549. 
[38] Prayag, G., \& Hosany, S. (2014). When Middle East meets West: Understanding the motives and perceptions of young tourists from United Arab Emirates. Tourism Management, 40, 35-45. DOI:10.1016/j.tourman.2013.05.003

[39] Plog, S. (2001). Why destination areas rise and fall in popularity: An update of a Cornell Quarterly classic. The Cornell Hotel and Restaurant Administration Quarterly, 42(3), 13-24. DOI:10.1016/S00108804(01)81020-X

[40] Rid, W., Ezeuduji, I. O., \& Pröbstl-Haider, U. (2014). Segmentation by motivation for rural tourism activities in The Gambia. Tourism Management, 40, 102-116. DOI:10.1016/j.tourman.2013.05.006

[41] Riley, R. W. (1995). Prestige Worthy Tourist Behavior. Annals of Tourism Research, 22(3), 630-49. DOI:10.1016/0160-7383(95)00009-U

[42] Ryan, R. M., \& Deci, E. L. (2000). Self-determination theory and the facilitation of intrinsic motivation, social development, and well-being. American Psychologist, 55, 68-78. DOI:10.1037110003066X.55.1.68

[43] Ryan, C., \& Glendon, I. (1998). Application of leisure motivation scale to tourism. Annals of Tourism Research, 25, 169-184. DOI:10.1016/S0160-7383(97)00066-2

[44] Stebbins, R. A. (1997). Identity and cultural tourism. Annals of Tourism Research, 24(2), 450-452. DOI:10.1016/S0160-7383(97)80014-X

[45] Steiger J H. (1990). Structural model evaluation and modification: an interval estimation approach. Multivariate Behavioral Research, 25, 173-180. DOI:10.1207/s15327906mbr2502_4

[46] Tao, C., P. F. J. Eagles, \& S. L. J. Smith. (2004). Profiling Taiwanese Ecotourists Using a Self-Definition Approach. Journal of Sustainable Tourism, 12(2), 149-68. DOI:10.1080/09669580408667230

[47] Thompson, C. W. (2002). Urban open space in the 21st century. Landscape and Urban Planning, 60, 5972. DOI:10.1016/S0169-2046(02)00059-2

[48] Ulrich, R. S., Simons, R. F., Losito, B. D., Fiorito, E., Miles, M. A., \& Zelson, M. (1991). Stress recovery during exposure to natural and urban environments. Journal of Environmental Psychology, 11, 201-230. DOI:10.1016/S0272-4944(05)80184-7

[49] Uysal, M., \& Jurowski, C. (1994). Testing the push and pull factors. Annals of Tourism Research, 21(4), 844-846. DOI:10.1016/0160-7383(94)90091-4.

[50] Weaver, D. B. (2002). Hard-Core Ecotourists in Lamington National Park, Australia. Journal of Ecotourism, 1(1), 19-35. DOI:10.1080/14724040208668110

Received: 2018-02-09

Accepted: 2018-04-10

\section{University of Kragujevac, Faculty of Economics, Serbia}

Veljko Marinkovic is an Associate Professor of Marketing Research and Consumer

Behaviour at the Faculty of Economics, University of Kragujevac, Serbia. He holds a

$\mathrm{PhD}$ in Business Management from the Faculty of Economics, University of Belgrade,

Serbia. He is a member of the Presidency of the Serbian Marketing Association (SeMA).

Veljko has authored a number of articles in the leading international journals

(International Journal of Information Management, Online Information Review,

International Journal of Tourism Research, Leisure Studies, Total Quality Management and Business Excellence, International Journal of Consumer Studies). His major interests are related to service quality, customer satisfaction and loyalty. He was member of the Programme or Organizing Committees of several Serbian or International

Conferences. He was also a researcher in several projects in the field of marketing.

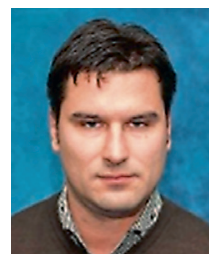




\section{Darko Dimitrovski}

Faculty of Hotel Management and Tourism in Vrnjačka Banja, University of Kragujevac Vojvođanska bb, 36210 Vrnjačka Banja, Serbia darko.dimitrovski@kg.ac.rs

Darko Dimitrovski is an Assistant Professor at the Faculty of Hotel Management and Tourism at the University in Kragujevac, Serbia. He holds a Ph.D. in Geography from the University of Belgrade. He is a member of a number of international associations (Association of Critical Heritage Studies, Regional Studies Association, Serbian Marketing

Association, etc). He has authored a number of articles in the leading peer reviewed international journals (Cities, Tourism Geographies, Journal of Travel and Tourism Marketing, Leisure Studies, British Food Journal, Tourism Management Perspectives, Tourism Review, Journal of Convention and Event Tourism and Marketing Intelligence \&

Planning). His research interest is largely focused on special interest tourism. He was engaged as a researcher in several international tourism related projects.

Vladimir Senić

Faculty of Hotel Management and Tourism in Vrnjačka Banja - University of Kragujevac Vojvođanska bb, 36210 Vrnjačka Banja, Serbia vsenic@yahoo.com

Vladimir Senić is a Full Professor with the Faculty of Hotel Management and Tourism in Vrnjačka Banja, University of Kragujevac. He completed his undergraduate and graduate studies at the David Eccles School of Business - University of Utah and obtained a PhD at the Faculty of Economics, University of Kragujevac. The main focus of his scientific work is primarily related to topics involving service quality, customer satisfaction, customer loyalty and recently the use of geographic information systems in everyday business activities of service companies. He is a member of the Serbian Marketing Association (SeMA). 